ks. Mieczystaw Olszewski Archidiecezjalne Wyższe Seminarium Duchowne w Biatymstoku

\title{
Ksiądz Michał Sopoćko jako profesor wykładowca w Wilnie i w Białymstoku
}

\section{FATHER MICHAEL SOPOCKO AS A PROFESSOR AND LECTURER IN VILNIUS AND IN BIAtYSTOK}

Fr. Michael Sopocko studied at the Faculty of Theology in Warsaw, where he earned two degrees of Master of Theology, there he gained his doctorate and his habilitation. After graduation he took a job as a lecturer at the Stefan Batory University in Vilnius, where he taught catechetics, homiletics and pastoral theology at the same time leading the master seminar of these items. Since 1947, he began teaching and educational work in the Archdiocesan Major Seminary in Bialystok.

Key words: Blessed Father Michael Sopocko, University of Warsaw, Stefan Batory University in Vilnius, Seminary in Bialystok, catechetics.

Osobę bł. ks. Michała Sopoćki łączy się najbardziej z apostolstwem Miłosierdzia Bożego. Tytuł „Apostoła Miłosierdzia Bożego” przypisuje się mu od momentu poznania się ze św. Faustyną. Apostolstwo Miłosierdzia Bożego nie umniejsza roli ks. Sopoćki jako naukowca, profesora i płodnego pisarza ${ }^{1}$. Z perspektywy czasu widać lepiej i można z należnym dystansem oceniać wydarzenia, człowieka i jego dorobek. 40 lat od śmierci ks. Michała Sopoćki (15 II 1975) stwarza dobrą okazję popatrzeć z pogłębioną oceną na naukową twórczość docenta USB

W ostatnich latach ukazuje sięjednak wiele artykułów i opracowań dotyczących także strony naukowej ks. Sopoćki i jego roli naukowca, pisarza i wykładowcy. 
i profesora w AWSD. Należy podkreślić, że Błogosławiony Michał podszedł do kultu Miłosierdzia Bożego w sposób w pełni teologiczny. $\mathrm{W}$ artykule ${ }^{2}$ pomijam sprawę kultu Miłosierdzia Bożego, wymaga ona bowiem osobnego opracowania. Artykuł ukazuje drogę naukową ks. Michała Sopoćki, jego dorobek naukowy i dzielenie się wiedzą jako wykładowcy w Wilnie i w Białymstoku.

\section{Studia i zdobywanie stopni naukowych przez ks. Michała Sopoćkę}

\section{Marzenia stają się realne}

Powyższe stwierdzenie nie mówi o trudnych okolicznościach realizacji marzeń ks. Sopoćki o studiach i pracy naukowej. Niekiedy realizowały się one w sposób całkowicie przypadkowy. W swoich Wspomnieniach bł. ks. Michał Sopoćko zaznacza, że:

praca naukowa była między innymi jednym z głównych zadań mojego życia. Jakkolwiek wyłącznie jej oddać się nie mogłem ze względu na obowiązki (...), korzystałem z każdej okazji, by w miarę możności ją kontynuować.

Pisze też, że podejmował w tym celu kroki przygotowawcze, a mianowicie uczył się prywatnie języków obcych: angielskiego i francuskiego, a także przypominał sobie język niemiecki, którego uczył się w szkole ${ }^{3}$. Przy tym należy dodać, że Michał był zawsze bardzo pilnym studentem tak w Seminarium Duchownym w Wilnie, jak i na studiach uniwersyteckich.

Chęć studiowania motywował ks. Sopoćko także nadchodzącymi dla Polski nowymi czasami i możliwością uzyskania przez Polskę niepodległości u końca I wojny światowej. Chęć pogłębienia wiedzy pedagogicznej z kolei wynikała u niego także z jego doświadczeń pracy w parafii, w której zakładał wiele szkół, o czym wspomina, że pragnął zorganizować szkoły w każdej większej wsi, ale ciągle brakowało mu nauczycieli ${ }^{4}$.

$2 \quad$ Artykuł jest poszerzonym opracowaniem referatu, który autor wygłosił z okazji obchodów 70-lecia istnienia Seminarium Duchownego w Białymstoku dnia 21 V 2015.

M. Sopoćko, Wspomnienia, „Wiadomości Kościelne Archidiecezji w Białymstoku" (dalej: WKAB) 13(1985) nr 3, s. 120. 
Tymczasem sytuacja polityczna gwałtownie się zmieniła, o której ks. Michał Sopoćko pisał w swoich Wspomnieniach z przeszłości:

Wreszcie gruchnęła wieść o pokoju Brzeskim z jego konsekwencjami. Wszystko to zapowiadało, że idzie nowy porządek, do którego trzeba było samemu należycie się przygotować i uzupełnić swoje braki w wiedzy szczególnie pod względem pedagogicznym, gdyż tu odczuwałem poważne luki. Powoli dojrzewała myśl wyjazdu do Warszawy na dalsze studia $^{5}$.

Stało się to w okolicznościach wyjątkowych; inwigilowany przez Niemców musiał uciekać z parafii, stąd udał się do Warszawy, jak pisze w Dzienniku:

... w pierwszych dniach października 1918 roku [6 października] znalazłem się w Warszawie. Tu na razie uciekinierzy musieli odbyć kwarantannę na Dworcu Gdańskim. Była to niedziela i poprosiłem komendanta, by mi pozwolił udać się do miasta dla odprawienia Mszy św. Komendant po krótkim wahaniu pozwolił mi udać się zupełnie do Warszawy. Przybyłem do św. Krzyża, gdzie zatrzymałem się w Konwikcie Teologicznym przy Wydziale Teologicznym nowo otwartego Uniwersytetu ${ }^{6}$.

Tak więc miało się zrealizować w życiu ks. Michała Sopoćki marzenie, zadanie życia, jak sam to nazywa, czyli praca naukowa?

\section{Studia i zdobywanie stopni naukowych}

Błogosławiony Michał jako student teologii od października 1918 roku pragnął pogłębiać swoją wiedzę, ukierunkowaną przede wszystkim na cele duszpasterskie. Dlatego pracując w wojsku i kontynuując rozpoczęte studia $\mathrm{z}$ teologii moralnej na Wydziale Teologicznym, jesienią 1922 roku zapisuje się na studia w Wyższym Instytucie Pedagogicznym w celu uzupełnienia swojej wiedzy z dydaktyki i pedagogiki. Na wiosnę 1924 roku ks. Michał Sopoćko przeprowadził badania nad dziećmi szkół podstawowych i młodzieży szkół średnich w sprawie wpływu alkoholu na poziom zdolności u młodzieży. Na podstawie tych badań napisał pracę dyplomową Alkoholizm a młodzież szkolna, opublikowaną w tym samym roku w „Przeglądzie Pedagogicznym”. Pracę tę oceniono bardzo wysoko, co sprawiło, że z powodu tych badań był

Ibidem, s. 111 .

$6 \quad$ Idem, Dziennik, (oprac., wstęp i przypisy H. Ciereszko), Białystok 2012, wyd. 2, s. 77-78. 
często zapraszany z referatami na temat walki z alkoholizmem ${ }^{8}$. Studia na Uniwersytecie Warszawskim ks. M. Sopoćko ukończył w 1923 roku, uzyskując tytuł magistra z zakresu teologii moralnej.

Zdobywanie stopni naukowych przez bł. Michała rodzi pewne pytania. Dzisiaj studiując na wyższej uczelni zdobywa się najpierw naukowy stopień magistra, potem doktorat, i ewentualnie habilitację i tytuł profesora. Ksiądz Sopoćko pisząc w Curriculum vitae zaznacza, że „studiowałem teologię moralną na Wydziale Teologicznym w Warszawie 1918-1923 i otrzymałem stopień magistra teologii 30 VI 1923 roku"9 . Nie podaje jednak tematu pracy magisterskiej. W „Dyplomie magisterskim z teologii" widnieje następujący zapis:

[Ks. Michał Sopoćko] po zdaniu przepisanych egzaminów z teologii, a zwłaszcza teologii moralnej, chwalebnie potwierdził znajomość nauki, a po wyznaniu wiary, został mu udzielony tytuł magistra z honorami i przywilejami, które przez szacowną Rzeczpospolitą Polski, także przez papieży udzielane są, co potwierdzamy tym pismem i uwierzytelniamy je pieczęcią ${ }^{10}$.

Aby wyjaśnić brak pisemnej pracy magisterskiej, należy sięgnąć do dziejów Akademii Duchownej, założonej w Wilnie w 1834 roku ${ }^{11}$. Zgodnie ze statutem Akademia Duchowna w Wilnie miała prawo nadawać stopnie naukowe rzeczywistego studenta, kandydata, magistra oraz doktora teologii i doktora prawa kanonicznego. Zgodnie z ogłoszonymi 22 września 1839 roku „Prawidłami nadawania stopni naukowych” do egzaminu magisterskiego dopuszczano tylko tych studentów, którzy osiągnęli bardzo dobre wyniki na egzaminach z przedmiotów głównych, którymi były Pismo Święte i wszystkie nauki teologiczne łącznie z patrologią oraz napisali dwie prace: jedną po łacinie, a drugą po rosyjsku na wyznaczone tematy ${ }^{12}$. Owe prace, nazwijmy je zaliczeniowymi, nie były pracami magisterskimi w rozumieniu obecnego szkolnictwa

$8 \quad$ Ibidem, s. 108.

$9 \quad$ Curriculum vitae AAB II 6.

10 Dyplom magisterski, AAB XI 4: „[Michał Sopoćko] postquam legitimis examinibus in Theologia speciatim in Theologia moralis, doctrinam probavit, fideique professionem emisit, MAGISTRI nomen et honores et privilegia, que a SERENISSIMA REPUBLICA POLONORUM, atque a Summis Pontificibus concessa sunt, contulimus in eiusque rei fidem litteras sigillo sanciendam curavimus. Datum Varsaviae, die XXX iunii anno Domini MCMXXIII."

11 A. Petrani, Nauka prawa kanonicznego $w$ Polsce $w$ XVIII-XIX wieku, Lublin 1961, s. 221; Zob. I. Wodzianowska, Rzymskokatolicka Akademia Duchowna $w$ Petersburgu 1842-1918, Lublin 2007, s. 22. 
wyższego. Ten system nauczania i uzyskiwania tytułu magistra został przyjęty w Rzymskokatolickiej Akademii Duchownej po przeniesieniu w roku 1842 Akademii Duchownej z Wilna do Petersburga. Warunkiem uzyskiwania tytułu magistra bez pisemnej rozprawy magisterskiej, a jedynie aktem upoważniającym do nadania stopnia magistra, były egzaminy z teologii. To zdaje się potwierdzać wyżej cytowany „Dyplom magisterski” ks. Sopoćki: że, „po zdaniu przepisanych egzaminów z teologii, a zwłaszcza teologii moralnej, chwalebnie potwierdził znajoHistoria mość nauki, a po wyznaniu wiary, został mu udzielony tytuł magistra".

W „Dyplomie ukończenia Studium Pedagogicznego” zaświadcza się, że

[Michał Sopoćko] ... zdał egzaminy z ogólnym wynikiem dobrym. Pracę piśmienną domową na temat „Alkoholizm wśród młodzieży szkolnej" ocenili pp. dr Józefa Jotejko i dr Tadeusz Jaroszyński jako bardzo dobrą. Wobec powyższego ks. Michał Sopoćko ma kwalifikacje na nauczyciela - MAGISTRA - podmiotów pedagogicznych w języku wykładowym polskim w szkołach średnich ogólnokształcących i seminariach nauczycielskich.

Z powyższego wynika, że ks. Michałowi Sopoćce nadano dwa stopnie magistra: najpierw na Wydziale Teologicznym Uniwersytetu Warszawskiego. Jednak sam Błogosławiony zaznacza w Curriculum vitae:

Studiowałem teologię moralną na Wydziale Teologicznym w Warszawie 1918-1923 i otrzymałem stopień Magistra Teologii 30 VI 1923 roku... Studiowałem pedagogikę na Wyższym Kursie Nauczycielskim w Warszawie i otrzymałem stopień Magistra Pedagogiki 24 VI $1924 \mathrm{roku}^{13}$.

Kolejne stopnie naukowe, które zdobył ks. Sopoćko to doktorat 1 III 1926 na Wydziale Teologicznym Uniwersytetu Warszawskiego oraz jak sam pisze, że: „W roku 1934 habilitowałem się w Warszawie i nadal pracowałem w charakterze docenta i zastępcy profesora U.S.B. w Wilnie" ${ }^{14}$.

\section{Praca naukowa na Uniwersytecie Stefana Batorego w Wilnie}

Kolejny etap pracy naukowej ks. Sopoćki był realizowany już na Uniwersytecie Stefana Batorego w Wilnie. Tak pisze on we Wspomnieniach:

Dnia 10 sierpnia 1928 roku Ministerstwo Wyznań Religijnych i Oświecenia Publicznego powierzyło mi zastępstwo na katedrze Teologii

13 M. Sopoćko, Curriculum vitae (brak daty), AAB II 6.

$14 \quad$ Idem, Przebieg studiów i prac ks. Michała Sopoćki (brak daty), AAB II 9. 
Pastoralnej Wydziału Teologicznego U.S.B. w Wilnie. Wprawdzie teologii pastoralnej jako takiej nie wykładałem (wykładał ją bowiem ks. Rektor Uszyłło), ale objąłem wykłady przedmiotów z teologią pastoralną ściśle związanych, a mianowicie homiletyki, katechetyki, pedagogiki oraz dodatkowo historii filozofii. Oprócz teoretycznych wykładów wymienionych przedmiotów prowadziłem seminarium teologii pastoralnej i proseminarium homiletyki, katechetyki i pedagogiki, zaprawiając alumnów praktycznie w dykcji, pisaniu i głoszeniu kazań, konspektów lekcji i prowadzenie ich w szkołach powszechnych ${ }^{15}$.

Tak więc poczynając od roku akademickiego 1928/29 ks. Sopoćko wykładał katechetykę (metodyka nauczania religii) po dwie godziny tygodniowo, homiletykę jedną godzinę tygodniowo wraz z prowadzeniem ćwiczeń praktycznych z tych przedmiotów. Ponadto od roku akademickiego 1928/29 do roku akademickiego 1938/39 prowadziłem wykłady z innych przedmiotów: przede wszystkim z teologii pastoralnej, a także z pedagogiki, historii filozofii, jak też wykłady z ascetyki mistycznej ${ }^{16}$.

Prowadzenie seminariów naukowych z homiletyki, katechetyki i teologii pastoralnej zaowocowało dziewięciu pracami magisterskimi napisanymi przez studentów teologii pod jego kierunkiem w latach 1935-1940. W roku akademickim 1935-1936: ks. Stanisław Fiedorczuk Ks. Stanistaw Konarski o religijno-moralnym wychowaniu młodzie $\dot{z} y^{17}$; w roku 1936-1937 ks. Władysław Giemżewski obronił pracę magisterską Charakterystyka kazań biskupa Adama Stanistawa Krasińskiego. Najobfitszym rokiem owocującym w prace magisterskie pisane pod kierunkiem ks. Sopoćki był rok akademicki 1939-1940. Oto magistranci ks. Sopoćki tego roku: ks. Józef Plewa, Wychowanie państwowe w świetle zasad nauki katolickiej; ks. Hipolit Chruściel, G. Kerschensteiner i J. Dewey o zajęciach ręcznych w szkole twórczej; ks. Stanisław Górski, Pojęcie $i$ cel wychowania domowego wg Cecylii Plater-Zyberkówny; ks. Stanisław Pyrtek, Apostolstwo świeckich kobiet; ks. Kazimierz Dmochowski, Ks. Piramowicz - nauczanie religii w szkołach; Karpiński Feliks, Ks. Tomasz Młodzianowski na tle swojej epoki; ks. Stanisław Bielawski, Koedukacja a ksztatcenie charakteru ${ }^{18}$.

$15 \quad$ M. Sopoćko, Wspomnienia, WKAB 13(1985) nr 4, s. 106.

Spis wykładów na trzy semestry z lat 1928/29-1938/39, passim, Arch. Prywatne

17 W swoich wspomnieniach ks. S. Fiedorczuk, Kartki z mojego życia. Wspomnienia $z$ lat 1920-1976, Białystok 1998 tak pisze na s. 12: „Homiletykę i pedagogikę nauczał świątobliwy kapłan ks. Michał Sopoćko. Pod jego kierunkiem pisałem pracę magisterską".

18 Zob. Wykaz prac magisterskich na Wydziale Teologicznym Uniwersytetu Stefana Batorego w Wilnie, AAB Białystok. 
Tematyka napisanych prac magisterskich pod kierunkiem ks. Sopoćki związana jest z wykładanymi przez niego przedmiotami. Należy podkreślić, że aktywność naukowa bł. ks. Sopoćki wskazuje na jego doskonałe przygotowanie naukowe, czego owocem były nie tylko prace magisterskie pisane pod jego kierunkiem, lecz także liczne jego publikacje związane z dziedzinami jego nauczania akademickiego, głoszone referaty na zjazdach diecezjalnych i ogólnopolskich, a ponadto przygotowywanie właściwych pomocy naukowych, w tym przypadku podręczników do homiletyki, katechetyki i pedagogiki.

Ks. Sopoćko przeniósł się w roku 1947 z Wilna do Białegostoku. Tutaj rozpoczął działalność dydaktyczną i duszpasterską. W Białymstoku wykładał te same przedmioty co i w Wilnie, związany najbardziej z białostockim Seminarium Duchownym.

\section{Katechetyka w ujęciu bł. Michała Sopoćki}

Dalsze rozważania opieram na twórczości katechetycznej ks. Sopoćki. Na jej tle uwidacznia się zarówno rzetelność naukowa ks. Sopoćki, jego gorliwość w zdobywaniu wiedzy i chęć jej przekazania swoim słuchaczom w sposób przystępny. Dlaczego na tle katechetyki? W ramach teologii pastoralnej mieści się katechetyka jako bardzo ważny przedmiot, oprócz homiletyki i liturgiki. Nauczanie katechetyczne nazywane także lekcjami religii wprowadzono do szkół w okresie Oświecenia w XVIII wieku, co było skutkiem objęcia sterów szkolnictwa przez państwo. Katechetyka wykładana na Uniwersytecie w Wiedniu najpierw wraz z teologią pastoralną, zostaje z niej wyodrębniona w 1812 roku. W połowie XIX wieku zaczyna się wielki ruch katechetyczny w Niemczech i w Austrii. Ważne dla nas jest ukazanie nauczania katechetyki w Rzymskokatolickiej Akademii Duchownej w Petersburgu (1842-1918). Tam część wykładów z teologii pastoralnej poświęcano zasadom katechizacji ${ }^{19}$.

Katechetyka tymczasem była traktowana jako przedmiot naukowy, ważny w programie studiów teologicznych uniwersyteckich i seminaryjnych. Tak ją określa ks. Piotr Poręba:

Katechetyka w najogólniejszym tego słowa znaczeniu jest teorią katechezy i katechizacji, czyli nauką o przepowiadaniu Słowa Bożego katechumenom, celem wprowadzenia ich w poznanie Boga przez wiarę

19 Zob. I. Wodzianowska, Rzymskokatolicka Akademia..., op. cit. s. 176-180. 
i życie Kościoła, Mistycznego Ciała Chrystusa, oraz o sposobach tego przepowiadania $^{20}$.

Ksiądz Poręba stwierdza też, że

Przepowiadanie to uwarunkowane jest od strony treści i zadań katechezy teologią pastoralną, od strony zaś sposobów i przedmiotu katechizacji - psychicznym i duchowym rozwojem katechumena oraz czynnikami jego środowiska wychowawczego, jak też i ogólną sytuacją wychowawczą Kościoła, a także i konkretną jego rzeczywistością $\mathrm{w}$ danym kraju ${ }^{21}$.

I stąd cytowany autor określa katechetykę jako naukę o podstawach teologicznych, psychologicznych, pedagogicznych i socjologicznych katechezy.

\section{Od metody monachijskiej do kerygmatycznej}

Katechetyka przechodziła różne etapy swego rozwoju. Błogosławiony ks. M. Sopoćko omawiając historię katechetyki przedstawia różne metody nauczania, które w znacznej mierze zależały od rozwoju sytuacji społecznej. Wpływ na katolicką katechezę w czasie Reformacji miały zakony zwalczające nowe prądy i w związku z tym położono nacisk na jakość katechezy poprzez przygotowanie odpowiednich podręczników. Pozytywny wpływ na katechetykę miało również wynalezienia druku, co umożliwiło uczącym się łatwiejszy dostęp do drukowanych katechizmów ${ }^{22}$.

Od połowy XVIII wieku, jak podkreśla, ustanowiono dla teologii pastoralnej osobne katedry naukowe, w Wiedniu już w 1777 roku, obejmujące nauczanie katechetyki i homiletyki. Jakkolwiek do teologii wkradały się wówczas fałszywe teorie filozoficzne i zwłaszcza racjonalizm, to nowe prądy, mówi ks. Sopoćko, pozytywnie wpływały na katechetykę, metoda scholastyczna bowiem ustąpiła miejsca metodzie psychologicznej i praktycznej, a historia święta zyskała większe znaczenie w nauczaniu, jednocześnie zwrócono większą uwagę na teoretyczne i praktyczne przygotowanie katechetów ${ }^{23}$.

Ksiądz Sopoćko zwrócił uwagę na szkody, jakie niósł ze sobą racjonalizm, który wciskał się nie tylko do metody katechetycznej, ale i do

P. Poręba,Dzieje katechetyki, [w:] M. Rechowicz(red.), Dzieje teologii katolickiej $w$ Polsce, t. 3 cz. 2, Lublin 1977, s. 124-125.

Ibidem, s. 125.

Zob. M. Sopoćko, Podręcznik katechetyki, [Białystok, br.], mps., s. 11.

Ibidem, s. 12. 
treści nauczania prawd wiary. Zaczęto bowiem bardziej zwracać uwagę na umysłowe rozwinięcie dziecka $\mathrm{z}$ pominięciem strony wychowawczej i kształcenia serca ${ }^{24}$. W kolejności tych zagadnień przedstawimy rozwój nauczania katechetycznego i udział w nim ks. Michała Sopoćki.

Podczas studiów ks. Michała Sopoćki w Wilnie dominującą była monachijska metoda katechetyczna, którą wypracowano i zastosowano do nauczania religii, na przełomie XIX i XX wieku w środowisku monachijskim i mającej swe zastosowanie w katechezie aż do lat sześćdziesiątych XX wieku. Do twórców metody monachijskiej zalicza się J. F. Herbarta i jego metodę stopni formalnych jeszcze z początku XIX wieku, A. Webera, a zwłaszcza najbardziej popularnego H. Stieglitza, który wprowadzał tę metodę do praktykowania jej w nauczaniu katechetycznym w pierwszym okresie jej stosowania w latach 1887-1898. Wysiłki tych autorów miały na celu przebudowanie metodyki katechezy, aby oprócz zapamiętywania treści, prowadziła ona do dobrego zrozumienia prawd wiary; w miejsce dedukcyjnego wprowadzono indukcyjny tok budowania etapów katechezy, zamiast objaśniania formuł katechizmowych, doprowadzanie do nich ${ }^{25}$.

W drugim okresie rozwoju monachijskiej metody katechetycznej w latach 1898-1908, biorąc pod uwagę jej walory dydaktyczne, przyjęto następujący schemat: 1. Przygotowanie, które miało wzbudzić zainteresowanie u katechizowanych; 2. Prezentacja danej prawdy czy kwestii moralnej w sposób zachęcający do jej zgłębienia poprzez opowiadanie, przypowieść, porównanie, anegdotę; 3. Wyjaśnienie jako proces psychologiczno-pastoralny wprowadzający uczniów drogą indukcyjną; 4. Synteza, czyli zebranie i włączenie wyników wyjaśnienia w całość wiedzy życiowej uczniów przedstawienie ich do zapamiętania; 5. Zastosowanie, tzn. ocena poznanych treści od strony praktycznejej. Ważny ostatni etap rozwoju monachijskiej metody katechetycznej w latach 1908-1928 związany jest z przesunięciem akcentów z aspektu metodologiczno-dydaktycznego nauczania religii na wychowawczy. W 1912 roku na I Kongresie Katechetycznym w Wiedniu potwierdzono zwycięstwo szkoły wychowawczej, popularnie nazywaną metodą monachijską. Uchwały tego Kongresu zatwierdzono w Polsce na Kongresie Katechetycznym w Krakowie w 1913 roku $^{27}$. W roku 1912 włączono

$24 \quad$ Ibidem, s. 12-13.

Zob.M. Zając, Monachijska metodakatechetyczna,Encyklopediakatolicka (dalej: EK), t. 13, Lublin 2003, kol. 97.

26 Ibidem.

$27 \quad$ Ibidem, kol. 14. 
również do monachijskiej metody katechetycznej zasadę szkoły pracy uznając, że najskuteczniejszym sposobem poznawania nowych treści jest uczenie się przez aktywne i twórcze własne działanie, a chodziło przy tym o przełamanie u katechizowanych postawy biernej recepcji. Podstawę kontaktu wychowawczego stanowiła rozmowa katechety z uczniami, a także prowadzenie zeszytu, śpiew, zadania domowe, przy uwzględnieniu także czynności manualnych m.in. rysowanie, malowanie, modelowanie; przyjęto również postulat stosowania zasady przeżyciowości w trakcie przekazu nowych treści, która miała aktywizować u uczniów ich władze intelektualne, wolitywne i emocjonalne ${ }^{28}$.

W Polsce monachijska metoda katechetyczna została zaadoptowana i rozwinięta przez ks. Walentego Gadowskiego, Zygmunta Bielawskiego, Jana Ciemniewskiego, a po II wojnie światowej stał się sławny podręcznik metodyczny Nauka Boża ks. Wincentego Zaleskiego, salezjanina, opracowany ściśle według stopni formalnych tejże metody katechetycznej.

Kiedy ks. M. Sopoćko studiował w Seminarium Duchownym w Wilnie w latach 1910-1914 nie była wykładana ani teologia pastoralna ani katechetyka. Ksiądz Sopoćko mógł mieć do czynienia z lekcjami religii jako uczeń w szkole podstawowej i w gimnazjum. Pogłębioną wiedzę z tych dziedzin zdobywał on dopiero podczas studiów na Uniwersytecie Warszawskim w latach 1918-1924. Na Wydziale Teologicznym w Warszawie ks. Sopoćko obrał jako kierunek studiów teologię moralną. Nie pomijał jednak korzystania z wykładów teologii pastoralnej. W dokumentach UW widnieje zapis, że ks. Sopoćko w semestrze zimowym 1922/23 chodził na wykłady z teologii pastoralnej prowadzone przez ks. dr Leona Śmiśniewicza (1891-1932), i że w semestrze zimowym 1921/22 uczestniczył w seminarium teologii pastoralnej tegoż profeso$\mathrm{ra}^{29}$. Ponadto ks. Sopoćko był słuchaczem wykładów ks. dr Antoniego Szlagowskiego na temat teorii i historii kaznodziejstwa ${ }^{30}$.

\section{Pierwszy podręcznik katechetyki autorstwa ks. Michała Sopoćki}

Wiedza dotycząca katechetyki znajdzie odzwierciedlenie w wykładach prowadzonych przez ks. prof. Michała Sopoćkę i w jego podręcznikach przygotowywanych jako maszynopis, które były przez słuchaczy powielane.

\footnotetext{
$28 \quad$ Zob. ibidem, kol. 98.

29 Teczka „Michał Sopoćko” Archiwum BUW, Dokument nr 316, s. 7.

$30 \quad$ Ibidem, Dokument nr 3475, s. 13.
} 
Jest zachowany egzemplarz skryptu z katechetyki zatytułowany Katechetyka ${ }^{31}$.

Ksiądz Sopoćko wydał w Białymstoku w 1948 roku na powielaczu skrypt do katechetyki, zachowujący wszystkie wymogi podręcznika ${ }^{32}$. Ponieważ ks. Sopoćko przyjechał z Wilna do Białegostoku w lipcu 1947, należy przypuszczać, że opracowanie Katechetyki jest powtórzeniem wydania wileńskiego. Na wstępie swego opracowania podaje ks. Sopoćko definicję tego przedmiotu: „Katechetyka jest umiejętnością, która podaje prawidła i reguły oparte na naturze ducha ludzkiego i doświadczeniu oraz dążące do celowego nauczania prawd wiary i moralności chrześcijańskiej". Sformułowanie to rozwija następująco:

nauczanie katechizmowe zmierza nie tylko do teoretycznego podawania prawd wiary i moralności, ma ono dążyć do wychowania chrześcijańskiego, ma ukształtować i udoskonalić człowieka w zasadach Kościoła świętego. Stąd przedmiotem katechetyki, która ma tym wszystkim kierować, będą nie tylko zasady kierujące wykładem prawd wiary, lecz także te prawidła wychowania ludzi w duchu chrześcijańskim, które katechecie ze względu na jego stanowisko są mu dostępne. Celem więc teoretycznych zasad katechetyki, stosownie do jej przedmiotu, jest podanie najodpowiedniejszych sposobów umysłowego i moralnego wychowania religijnego, jak również wskazanie dróg, jakimi katecheta ma dążyć do owego celu ${ }^{33}$.

Dalej podkreśla Błogosławiony bliskość katechetyki do pedagogiki, o ile ma ona na celu wychowanie religijno-moralne, jeżeli zaś dotyczy procesu nauczania, wówczas jest działem metodyki. Stąd ks. Sopoćko uważa, że pedagogika i metodyka wykładu zasad wiary chrześcijańskiej - to przedmiot i cele katechetyki. Takie ujęcie rozumienia katechetyki posiłkując się osiągnięciami pedagogiki w zastosowaniu do katechetyki, wskazuje wyraźnie na model monachijskiej metody katechetycznej w treści Podręcznika katechetyki.

Opracowanie swoje dzieli na cztery części: o katechetyce w ogóle, osoba katechety, o nauczaniu w ogóle oraz o nauczaniu religii i o wychowaniu chrześcijańskim, czyli metodyka nauczania religii inaczej mówiąc dydaktyka szczegółowa ${ }^{34}$. I dodaje, że świadectwo katechety polega na ukazaniu działającej obecności Boga we własnym życiu. Ponadto katecheta powinien odznaczać się dobrą znajomością Pisma

Katechetyka. Wykłady ks. prof. M. Sopoćki na Wydz. Teologicznym U.S.B. r. a. 1934-35 [s. 1., s. n.].

M. Sopoćko, Katechetyka. Wykłady ks. prof. dr Michała Sopoćki, Białystok 1948.

M. Sopoćko, Katechetyka, op. cit., s. 3.

Ibidem, s. 2; s. $36 \mathrm{nn}$. 
Świętego. W części II opracowania, w której mówi o dydaktyce ogólnej posiłkuje się osiągnięciami ówczesnej pedagogiki, o której wiedzę zdobywał na Wyższym Instytucie Pedagogicznym w Warszawie.

Na początku i w pierwszej połowie XX wieku coraz bardziej zwracano uwagę na wychowawcze zadania katechezy. Dydaktyka korzystała z najnowszych osiągnięć psychologii, o których ks. Sopoćko mówi jako o koniecznych w dotarciu do uczniów zgodnie z ich fazami rozwoju. Korzystanie ze znajomości rozwoju dzieci i młodzieży było też właściwością metody monachijskiej. Stosowana w niej metoda psychologiczna, uwzględniająca psychiczny rozwój dziecka, jego zainteresowania, zdolności i naturalne skłonności, powiązana z logicznymi prawidłami jego myślenia oraz biorąca pod uwagę naturę przedmiotu nauczania - stała się powszechnym postulatem nauczania zarówno w dydaktyce świeckiej, jak i w katechetyce. Wprowadzanie metody psychologicznej stało się ważnym dziełem metody monachijskiej ${ }^{35}$. Metoda ta doprowadziła do zmian nie tylko w samej katechezie, przekształcając ją w jednostkę metodyczną, ułożoną logicznie i powiązaną psychologicznie, ale przede wszystkim w procesie nauczania wychodząc nie od abstraktu - definicji, lecz od konkretu zdążając do abstraktu, od rzeczy do pojęć, zgodnie z fazami rozwojowymi dzieci i młodzieży ${ }^{36}$.

Ciągle jednak poszukiwano nowych rozwiązań dla katechetyki, aby móc jak najlepiej dotrzeć do uczestników katechezy. Stąd w tych poszukiwaniach chodziło nie tylko o nauczanie wychowawcze, miało ono być wychowaniem personalistycznym. Tak więc w procesie wychowawczym zasadniczą rolę odgrywała postawa i przykład katechety. Ksiądz Sopoćko poświęca temu zagadnieniu jedną z części podręcznika, w której uwzględnia walory intelektualne, emocjonalne, moralne i nadnaturalne, a także fizyczne walory katechety ${ }^{37}$.

\section{Nowy (drugi) podręcznik katechetyki autorstwa ks. Michała Sopoćki}

Ksiądz Sopoćko był zorientowany w najnowszych prądach katechetycznych i wykorzystywał je w praktyce, uzupełniając swoim doświadczeniem $\mathrm{w}$ nauczaniu tego przedmiotu na USB, podobnie i w Seminarium Duchownym w Białymstoku. Dowodem na to jest przygotowany przez niego egzemplarz podręcznika katechetyki, który nie posiada daty, ale jest unowocześnioną wersją podręcznika z 1948

\footnotetext{
$35 \quad$ P. Poręba, Dzieje katechetyki..., op. cit., s. 138-139.

36 Zob. ibidem, s. 139.

37 M. Sopoćko, Podręcznik katechetyki, [Białystok, br.], s. 118 passim.
} 
roku. Język jest bardziej przystępny, bowiem opuszcza cytaty w języku łacińskim, a podaje je w języku polskim. Treść nowego ujęcia różni się od poprzedniego wydania powielaczowego tym, że ma zmieniony układ materiału: pojęcie i historia katechetyki; o nauczaniu w ogólności; o nauczaniu religii; osoba katechety i ucznia ${ }^{38}$. W tym wydaniu Katechetyki ks. Sopoćko charakteryzuje nauczanie religii:

Nauczanie religii zmierza nie tylko do teoretycznego podawania zasad wiary i norm moralności. Ale ma dążyć do wychowania chrześcijańskiego. Stąd przedmiotem katechetyki będą nie tylko zasady, kierujące nauczaniem prawd wiary, lecz także prawidła wychowania ludzi w duchu chrześcijańskim (...). Celem więc teoretycznych zasad katechetyki jest podanie najodpowiedniejszych sposobów umysłowego i moralnego wychowania religijnego, jak również wskazanie dróg, jakimi katecheta ma dążyć do tak wzniosłego celu ${ }^{39}$.

W rozdziale dotyczącym celu nauczania ks. Sopoćko podkreśla znaczenie psychologii i dzięki osiągnięciom w poznawaniu ludzkiej natury, powinno się najpierw dowiedzieć, kim jest człowiek, a dopiero potem poznać, co czynić powinien. Obecnie, mówi ks. Sopoćko, ścierają się dwa zasadnicze poglądy na stan natury ludzkiej: katolicki i materialistyczny. Rzecznicy nauki katolickiej, idący za św. Tomaszem, uznają, że człowiek składa się z ciała i duszy nieśmiertelnej. Dusza jest substancją duchową, dzięki której człowiek żyje, czuje i rozumie. W człowieku funkcjonuje życie wegetatywne, zmysłowe i duchowe. Każde z nich kieruje się własnymi potrzebami, które należy zaspokajać. Ale siłą kierowniczą w człowieku jest strona rozumna, duchowa. Tymczasem wskutek grzechu pierworodnego często się zdarza, że pod wpływem pożądania zmysłowego rozum w swych funkcjach bywa zawieszony albo przynajmniej osłabiony, a osłabiona wola daje się unieść namiętnościom. Grzech więc pierworodny zburzył w człowieku harmonię władz, chociaż ich nie zniszczył. Mając na uwadze ten stan ludzkiej natury, celem nauczania wychowującego będzie wewnętrzne zharmonizowanie człowieka. Tak wyartykułowany przez ks. Sopoćkę cel wychowania wyraźnie nawiązuje do poglądów Mikołaja Łęczyckiego, którego osoba i naukowy dorobek były podstawą habilitacji bł. Michała. Mikołaj Łęczycki jako punkt wyjścia w wychowaniu podkreślał harmonię wewnętrzną między władzami zmysłowymi i duchowymi

38 Brak daty tego opracowania utrudnia podanie dokładnego roku wydania. Natomiast z cytowanej literatury m.in. J. Pastuszka, Charakter człowieka, Lublin 1959 czy A. Żychliński, Rozważania filozoficzne i teologiczne, Poznań 1959, można wnioskować, że nowe wydanie Katechetyki ks. Sopoćki miało miejsce u początku lat sześćdziesiątych. 
człowieka ${ }^{40}$. Bierze pod uwagę naturę ludzką z jej stroną zmysłową i duchową, w których funkcjonowaniu widzi on możliwość zharmonizowania ich pod kierunkiem strony duchowej człowieka, czyli zharmonizowanie natury niższej człowieka z wyższą przez poddanie namiętności rozumowi i woli ${ }^{41}$.

\section{Trzecie uzupełnione o elementy kerygmatyczne wydanie Podrecznika katechetyki}

Kolejna próba unowocześnienia podręcznika katechetyki przez ks. Sopoćkę opiera się w zasadzie na jego drugim opracowaniu podręcznika, ale treść jest uzupełniana wieloma wstawkami. Wszystkie dotyczą nowej metody stosowanej już w katechezie, a mianowicie metody kerygmatycznej.

W katechetyce wciąż poszukiwano nowych rozwiązań w nauczaniu religii, aby można było jak najlepiej dotrzeć do katechumenów. Działo się to nie bez wpływu teologii pastoralnej ${ }^{42}$. Odnowę kerygmatyczną w katechetyce zapoczątkowało dzieło J. A. Jungmanna, Die Frohbotschaft und unsere Glaubensverkuendigung (Regensburg 1936). Jego zdaniem nie teologia, lecz kerygma, z której ta pierwsza wyrosła, jest podstawą katechezy. Katecheza jest przede wszystkim przepowiadaniem słowa Bożego, a nie przekazywaniem pewnego systemu prawd religijnych, ona głosi słowo i miłość Boga, szukającego człowieka. Stąd też i skuteczność katechezy nie zależy od dobrych metod przekazywania prawd religijnych, lecz od samej treści. Tak więc katecheza kerygmatyczna jest ukierunkowana przede wszystkim na treść, a nie na metodę ${ }^{43}$.

Punktem wyjścia tej katechezy nie jest wiedza religijna, ani związana z nią metoda nauczania, lecz słowo Boże, które Bóg objawił człowiekowi. To Objawienie Boże stanowi jej istotę, staje się ono przepowiadaniem Boga żywego, działającego w dziejach ludzkich i w życiu poszczególnego człowieka. Nazywa się tę zasadę podstawą teocentryczną. Po niej idzie podstawa chrystocentryczna. Plan Zbawienia człowieka, który Bóg wypełnia wobec ludzi, dokonuje się w Osobie Jezusa Chrystusa, który przyszedł na świat, aby poprzez śmierć i Zmartwychwstanie doprowadzić dzieło Bożego Zbawienia do końca. Chrystus Pan dokonuje w Kościele dzieła Zbawienia, bowiem

\footnotetext{
$40 \quad$ Ibidem, s. 20-21.

${ }_{41}$ M. Sopoćko, Mikołaj Łęczycki o wychowaniu duchowem, Wilno 1935, s. 34 nn.

$42 \quad$ P. Poręba, Dzieje katechetyki..., op. cit., s. 166.

$43 \quad$ Zob. Ibidem.
} 
żyje w nim i jako jego Głowa działa w nim. Stąd też przepowiadanie słowa Bożego w Kościele jest działaniem Chrystusa. Także przepowiadanie katechetyczne powinno być eklezjocentryczne. Kolejną cechą katechezy kerygmatycznej jest to, że opiera się ona na Biblii i ukazuje zbawcze plany i działanie Boże w historii, jak i w życiu każdego człowieka w każdorazowej rzeczywistości Kościoła. Głoszenie słowa Bożego i ukazywanie działalności Boga dokonuje się w sposób najbardziej czytelny w sprawowanym kulcie Boga w liturgii świętej. Aspekt liturgiczny katechezy kerygmatycznej jest szczególnym zadaniem nauczania katechetycznego. A ponieważ ludzie wierzący żyją w zmieniającej się rzeczywistości socjalnej i eklezjalnej, katecheza kerygmatyczna ma te elementy uwzględniać, aby głoszenie Bożego Zbawienia docierało do wiernych w każdej ich sytuacji życia. Ta podstawa środowiskowa jest więc także ważnym elementem katechezy kerygmatycznej ${ }^{44}$.

Katecheza kerygmatyczna uwzględniając jej podstawowe postulaty zmierza do osiągnięcia właściwych dla niej celów: przede wszystkim usiłuje doprowadzić do osobowego spotkania człowieka z Bogiem i wywołać u niego odpowiedź przez zaangażowanie się w sprawy Zbawienia. Nauczanie kerygmatyczne pragnie doprowadzić do wewnętrznego nawrócenia, polegającego na dogłębnym przejęciu się faktem, że Królestwo Boże już się rozpoczęło i należy tylko pójść za wezwaniem Bożym. Chodzi więc o odnowienie aktu wiary, aby katechumen osobowym aktem wiary włączył się w rzeczywistość przedstawioną w Objawieniu Bożym, co wymaga pełnego zaangażowania się całej osoby w to Boże dzieło i zgody na wszystkie jego życiowe konsekwencje. W dziele doprowadzenia ucznia do takiej decyzji rola katechety zmienia się z roli nauczyciela w herolda głoszącego orędzie Bożego zbawienia ${ }^{45}$.

Wspomniane uzupełnienia podręcznika katechetyki autorstwa ks. Michała Sopoćki mają swoją ważną wymowę, stawiał on bowiem na najnowsze trendy zarówno w teologii pastoralnej, jak i w katechetyce. Już w pierwszym rozdziale tego podręcznika katechetyki podkreśla ks. Sopoćko znaczenie ujęcia kerygmatycznego katechezy:

Podawane prawdy religijne mają stać się wartościami osobistymi ucznia, który winien je przeżyć, aby realizować w życiu i ukształtować styl chrześcijańskiego postępowania. Same tedy zasady pedagogiczne i dydaktyczne tu nie wystarczą, chodzi bowiem nie o magazynowanie wiedzy, jaka może się przydać w przyszłości, lecz o budzenie życia

\footnotetext{
$44 \quad$ Ibidem, s. 166 i passim.

45 Zob. ibidem, s. 170-171.
} 
chrześcijańskiego zaraz, aby się ono rozpoczęło w tej chwili. To się da osiągnąc przez tzw. nauczanie kerygmatyczne ${ }^{46}$.

Nieco dalej wyjaśnia, że

w nauczaniu kerygmatycznym chodzi nie tylko o poznanie prawd objawionych, ale o ich jednoczesne przeżywanie w uczeniu się i nauczaniu. Akt przeżycia zaś różni się zasadniczo od aktu nauczania: w przeżyciu bowiem spotyka się nie podmiot z przedmiotem - jak w nauczaniu lecz podmiot z podmiotem, czyli z osobą - z Chrystusem. Gdy katecheta przemawia, działa sam Chrystus ${ }^{47}$.

W świetle tych rozważań ks. Sopoćko charakteryzuje katechetykę w nowym kerygmatycznym rozumieniu:

jako naukę o zasadach nauczania wiary i moralności chrześcijańskiej oraz wychowania religijno-moralnego tak, aby uczeń przeżywał poznane prawdy i ujawniał to w modlitwach, liturgii i życiu chrześcijańskim ${ }^{48}$.

W rozdziale Historia katechetyki umieszcza ks. Sopoćko teksty dotyczące metody kerygmatycznej w nauczaniu prawd wiary. Mówi o bardzo ważnej roli katechety:

W katechezie kerygmatycznej, która jest bardziej przepowiadaniem niż nauką, katecheta jest nie tylko nauczycielem i wychowawcą, ale nadto jest zwiastunem Dobrej Nowiny, heroldem Chrystusowym, echem głosu Bożego, pośrednikiem między słowem Bożym a słuchaczem ${ }^{49}$.

Autor Podręcznika katechetyki dodaje:

Kerygma pojęta w ten sposób nie jest przewrotem w katechizacji, lecz jej dalszym rozwojem. Nie przekreśla ona zdobytych dotychczas sukcesów dydaktycznych i pedagogicznych, lecz przyjmuje, podporządkowuje sobie i wciąga w swą służbę ${ }^{50}$.

W rozdziale „metodyka nauczania religii” (dydaktyka szczegółowa) omawiając nauczanie historii biblijnej ponownie nawiązuje do katechezy kerygmatycznej:

W katechezie kerygmatycznej historia biblijna uzyskuje swój charakter historii zbawienia, opisując żywe słowa i czyny Boże. Występuje tu Bóg nie jako odległa idea, ale jako Bóg żywy, działający i uszczęśliwiający

M. Sopoćko, Podręcznik katechetyki, op. cit., uzup. s. 3.

47 Ibidem.

48 Ibidem, 3-a.

Ibidem, uzup. do s. 10; por. J. Burzyński, O nauczaniu kerygmatycznym, „Katecheta" 6(1962), s. 321. 
człowieka. Wydarzenia biblijne mają odsłaniać nadprzyrodzoną rzeczywistość, do której wychowanek winien dotrzeć. Głoszenie historii zbawienia jest zarazem przepowiadaniem naszego obecnego zbawienia w Chrystusie. Przywrócenie Pismu św. dominującej roli w nauczaniu religii wymaga przesunięcia akcentów w samej katechezie biblijnej, która ma odsłonić nie tylko fakt historyczny, lecz nadto nadprzyrodzoną rzeczywistość. Do tej nadprzyrodzonej rzeczywistości katecheza musi dotrzeć, wyjaśnić ją i wskazać zbawczą działalność. Głoszenie więc historii zbawienia jest zarazem przepowiadaniem naszego obecnego zbawienia w Chrystusie. Chodzi o to, by katecheza była czymś więcej, niż nauczaniem, chodzi o uwypuklenie momentów duszpasterskich i teologicznych, które były zazwyczaj niedoceniane ${ }^{51}$.

W innych działach nauczania religii: w nauczaniu liturgii czy historii Kościoła, ks. Sopoćko wskazuje również na znaczenie metody kerygmatycznej w ich nauczaniu. Idea przekazywania żywej obecności Boga we Mszy św., w sakramentach świętych pogłębia późniejsze w nich uczestnictwo, bowiem

to, czego nauczamy w katechezie, to w liturgii jest rzeczywistością zbawienia. W liturgii Chrystus jest obecny jako ten, który działa. Akcja liturgiczna jest skutecznym znakiem życia i obecności Chrystusa. (...) Stąd zadaniem katechezy z wykorzystaniem metody kerygmatycznej jest wtajemniczeniem wychowanka w liturgię, a naświetlenie liturgii treściami biblijnymi będzie jednym z najistotniejszych elementów wychowania liturgicznego. Katecheza powinna odbywać się w duchu liturgii, uczestniczyć w jej klimacie i rozwijać się w atmosferze wiary ${ }^{52}$.

Ksiądz Sopoćko widzi wielką pomoc w nowej katechezie kerygmatycznej w nauczaniu liturgii w katechezie.

Odrodzenie kerygmatyczne pogłębiło związek katechezy z liturgią. Okazało się, że to, czego w katechezie nauczamy, w liturgii jest rzeczywistością zbawienia. W liturgii Chrystus jest obecny jako ten, który działa. Kościół odtwarzając w symbolach liturgicznych gesty Chrystusa, jego słowa i czyny, sprowadza na nas te skutki, które Chrystus wywoływał w uczniach. Akcja liturgiczna jest skutecznym znakiem życia samego Chrystusa. Zadaniem katechezy będzie wtajemniczyć wychowanka w liturgię, przygotować go do jej przeżywania i aktywnego w niej uczestnictwa. Katecheza ma otwierać oczy wychowanka na ten nowy świat, w którym gesty, rzeczy i obrzędy przekazują zbawienie człowiekowi ${ }^{53}$.

$51 \quad$ Ibidem, uzup. do s. 76.

52 Ibidem, uzup. do s. 90.

53 Ibidem, uzup. do s. 90. 
Szczególne znaczenie w nauczaniu katechetycznym ma historia biblijna. Zbawcze wydarzenia biblijne dokonane przez Jezusa Chrystusa, Syna Bożego, w Jego nauczaniu, śmierci i Zmartwychwstaniu głoszone przez Apostołów są wzorcem dla katechezy kerygmatycznej. Dlatego też ks. Sopoćko podkreśla znaczenie nauczania historii biblijnej w ujęciu kerygmatycznym:

W katechezie kerygmatycznej historia biblijna odzyskuje swój charakter historii zbawienia, opisując żywe słowa i czyny Boże. Występuje tu Bóg nie jako idea odległa, ale jako Bóg żywy, działający i uszczęśliwiający człowieka. W tej kategorii wydarzenia biblijne mają odsłaniać nadprzyrodzoną rzeczywistość, do której wychowanek winien dotrzeć. Głoszenie historii zbawienia jest zarazem przepowiadaniem naszego obecnego zbawienia w Chrystusie. (...) Przywrócenie Pismu św. roli dominującej w nauczaniu religii wymaga przesunięcia akcentów również w samej katechezie biblijnej, która ma odsłonić nie tylko fakt historyczny, lecz nadto nadprzyrodzoną rzeczywistość ${ }^{54}$.

\section{Podsumowanie}

Biorąc pod uwagę kształcenie się ks. Sopoćki i jego drogę jako naukowca i oceniając naukowe opracowania podręczników do katechetyki, to trzeba stwierdzić, że ks. Sopoćko miał głęboką wiedzę dotyczącą tego przedmiotu. Każde z tych opracowań uwzględniały ówczesne trendy w teologii, a zwłaszcza w teologii pastoralnej i w katechetyce. Pierwsze opracowanie podręcznika, które powstało jeszcze w okresie międzywojennym, gdy ks. prof. Sopoćko był wykładowcą tych przedmiotów pastoralnych na USB, nosi w sobie elementy metody monachijskiej, z jej formalnymi etapami godziny lekcyjnej w nauczaniu religii. W drugim opracowaniu podręcznika zauważalny jest wpływ pedagogiki potwierdzający ówczesny kierunek pedagogiczno-wychowawczy. Położenie nacisku na wychowanie religijno-moralne w podręczniku katechetyki u ks. Sopoćki wskazuje na jego dobre przygotowanie pedagogiczne, które zdobył podczas studiów w Wyższym Instytucie Pedagogicznym w Warszawie. Trzecie wydanie podręcznika opiera się na wydaniu drugim, z tym że został on uzupełniony o uwagi dotyczące kierunku kerygmatycznego w katechezie. W wielu miejscach opracowania wskazuje na wartości metody kerygmatycznej. Te uzupełnienia wniesione do podręcznika, jakkolwiek świadczą o zainteresowaniu Błogosławionego Michała nowymi trendami aktualnymi przed Soborem Watykańskim II i mające wpływ, gdy chodzi o kierunek kerygmatyczny

54 Ibidem, uzup. do s. 76, 
w przepowiadaniu, na formułowanie dokumentów soborowych językiem w duchu kerygmatycznym, co podkreśla ks. Sopoćko:

Uchwały Soboru ostatniego wymagają, by całe wychowanie seminaryjne zabiegało około formacji kerygmatycznej katechety i wyrabiało w nim istotne cechy zwiastuna wiary, świadomość posłannictwa, gotowość służenia drugim oraz oddania się Chrystusowi ${ }^{55}$.

Uzupełnienia te nie sprawiają jeszcze tego, że jest to podręcznik katechetyki kerygmatycznej. Uzupełnienia czy wstawki mówią o aktualizowaniu wiedzy katechetycznej przez Błogosławionego o najnowsze trendy katechetyczne. Szkoda tylko, że ks. Sopoćko nie mógł już przedstawiać tych najnowszych osiągnięć katechetycznych podczas prowadzenia wykładów w Seminarium Duchownym w Białymstoku, został bowiem zwolniony z pracy w Seminarium z końcem roku akademickiego 1961/1962.

Charakterystyczne dla bł. ks. Michała Sopoćki było nie tylko jego pełne zaangażowanie $\mathrm{w}$ działalność naukową i praktyczną $\mathrm{w}$ dziedzinie katechetyki, ale też kierowane do świeckich nauczanie katechetyczne, przygotowujące ich do prowadzenia katechezy w szkołach. Konieczność współpracy ze świeckimi w dziedzinie nauczania religii, ks. Sopoćko dostrzegł już pracując jako wikariusz w parafii Taboryszki. Po wyższych studiach mając profesjonalne przygotowanie katechetyczne i pedagogiczne podejmował kształcenie świeckich w formie kursów katechetycznych zarówno w Wilnie jak i w Białymstoku. Organizował również inteligencję Wilna, a potem Białegostoku angażując wielu do aktywnego uczestnictwa w życiu Kościoła.

Słowa klucze: Błogosławiony ks. Michał Sopoćko, Uniwersytet Warszawski, Uniwersytet Stefana Batorego w Wilnie, Wyższe Seminarium Duchowne w Białymstoku, katechetyka.

\section{Bibliografia:}

1. Burzyński J., O nauczaniu kerygmatycznym, „Katecheta” 6(1962).

2. Fiedorczuk S., Kartki z mojego życia. Wspomnienia z lat 1920-1976, Białystok 1998.

3. Pastuszka J., Charakter człowieka, Lublin 1959.

4. Petrani A., Nauka prawa kanonicznego w Polsce $w$ XVIII-XIX wieku, Lublin 1961.

5. Poręba P., Dzieje katechetyki, [w:] M. Rechowicz (red.), Dzieje teologii katolickiej $w$ Polsce, t. 3 cz. 2, Lublin 1977.

6. Sopoćko M., Curriculum vitae AAB II 6.

55 Ibidem, uzup. do s. 10. 
7. Sopoćko M., Dziennik, (oprac., wstęp i przypisy H. Ciereszko), Białystok 2012, wyd. 2.

8. Sopoćko M., Katechetyka. Wykłady ks. prof. dr Michała Sopoćki, Białystok 1948.

9. Sopoćko M., Mikołaj Łęczycki o wychowaniu duchowem, Wilno 1935.

10. Sopoćko M., Podręcznik katechetyki, [Białystok, br.], mps.

11. Sopoćko M., Przebieg studiów i prac ks. Michała Sopoćki (brak daty), AAB II 9.

12. Sopoćko M., Wspomnienia z przeszłości (Życiorys napisany własnymi słowami), „Wiadomości Kościelne Archidiecezji w Białymstoku” 13(1985) nr 2.

13. Sopoćko M., Wspomnienia, „Wiadomości Kościelne Archidiecezji w Białymstoku" 13(1985) nr 3.

14. Sopoćko M., Wspomnienia, ,Wiadomości Kościelne Archidiecezji w Białymstoku" 13(1985) nr 4.

15. Wodzianowska I., Rzymskokatolicka Akademia Duchowna w Petersburgu 1842-1918, Lublin 2007.

16. Zając M., Monachijska metoda katechetyczna, [w:] Encyklopedia katolicka, t. 13, Lublin 2003.

17. Żychliński A., Rozważania filozoficzne i teologiczne, Poznań 1959. 